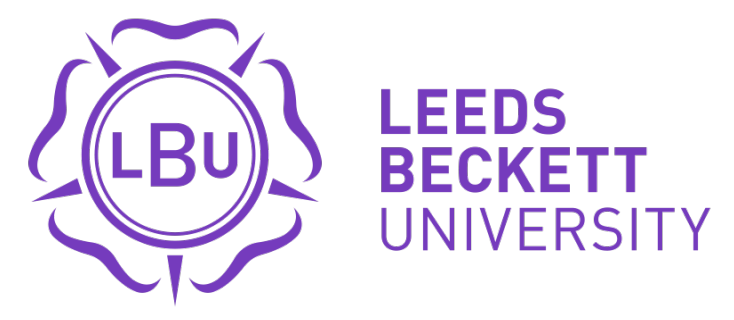

Citation:

Purcell, TF and Fernandez, N and Martinez, E (2017) Rents, knowledge and neo-structuralism: transforming the productive matrix in Ecuador. Third World Quarterly: journal of emerging areas, 38 (4). pp. 918-938. ISSN 1360-2241 DOI: https://doi.org/10.1080/01436597.2016.1166942

Link to Leeds Beckett Repository record:

https://eprints.leedsbeckett.ac.uk/id/eprint/2610/

Document Version:

Article (Accepted Version)

The aim of the Leeds Beckett Repository is to provide open access to our research, as required by funder policies and permitted by publishers and copyright law.

The Leeds Beckett repository holds a wide range of publications, each of which has been checked for copyright and the relevant embargo period has been applied by the Research Services team.

We operate on a standard take-down policy. If you are the author or publisher of an output and you would like it removed from the repository, please contact us and we will investigate on a case-by-case basis.

Each thesis in the repository has been cleared where necessary by the author for third party copyright. If you would like a thesis to be removed from the repository or believe there is an issue with copyright, please contact us on openaccess@leedsbeckett.ac.uk and we will investigate on a case-by-case basis. 


\title{
Rents, Knowledge and Neostructuralism: Transforming the Productive Matrix in Ecuador
}

\author{
Thomas F. Purcell ${ }^{a}$, Nora Fernandez* and Estefania Martinez* \\ ${ }^{a}$ Leeds Beckett University, Politics and Applied Global Ethics, Leeds LS1 3HE, UK \\ * Centro Nacional de Estrategia para el Derecho al Territorio (CENEDET) Instituto de \\ Altos Estudios Nacionales, Quito, Ecuador.
}

Thomas F. Purcell T.F.Purcell@ leedsbeckett.ac.uk +44 (0)7879448236 (corresponding author) Thomas Purcell has a PhD in Politics from The University of Manchester. He is currently Senior Lecturer in Politics and International Relations at Leeds Beckett University. Until recently he was the Sub-Director of CENEDET, at the Instituto de Altos Estudios Nacionales (IAEN). His research interests lie in the political economy of development with a regional focus on Latin America and Southern Europe. He is the co-author of The Limits to Capital in the European Periphery: Capitalism, Crisis and Revolt in Spain, International Political Economy Series (Basingstoke: Palgrave). His current research focuses upon the political economy of 'postneoliberalism' in Ecuador and Venezuela.

Nora Fernandez has an Msc in Economics from FLACSO Ecuador. She is currently a research and teaching member of CENEDET at the Instituto de Altos Estudios Nacionales (IAEN). Her research focuses upon historical and contemporary processes of capital accumulation and forms of uneven development in Ecuador.

Estefania Martinez has an MA in Socio-Environmental Studies from FLACSO Ecuador. She is currently a research and teaching member of CENEDET, at the Instituto de Altos Estudios Nacionales (IAEN). Her research interests are in sociological theory and the political economy of development in Latin America, with an empirical focus on Ecuador and Colombia.

\section{Acknowledgements}

The authors would like to thank Japhy Wilson, Greig Charnock, the CENEDET team and an anonymous reviewer for their helpful comments on earlier drafts of this paper. The usual caveat applies.

\section{Word count}

Text: 7,063

Footnotes: 1,139 


\title{
Rents, Knowledge and Neostructuralism: Transforming the Productive Matrix in Ecuador
}

\author{
This paper explores the relationship between ground-rent, production and \\ knowledge in Ecuador's neostructuralist state-led project to transform the \\ productive matrix. Based upon insights from the Marxian approach to the critique \\ of political economy, we interrogate how neostructuralism has conceptualized the \\ relationship between 'natural resource income' and 'knowledge-based' economic \\ development. The paper argues that a rent-theoretical perspective, that takes \\ seriously the regional unfolding of uneven geographical development in Latin \\ America, can highlight the limits of a national development plan conceived \\ according to the logic of Schumpeterian efficiency. In doing so the paper \\ identifies the contradictory relationship between natural resource exports, state- \\ led development and capital accumulation. On this basis the paper offers a \\ historically and empirically informed critical analysis of selective import \\ substitution industrialisation and vanguard science and technology strategies \\ designed to transition Ecuador away from primary resource dependence.
}

Keywords: neostructuralism; Ecuador; Marxism; rent, knowledge, Schumpeter, uneven development

One of the countries that emerged relatively quickly from the 2008 global financial crisis was Ecuador - a small, dollarized and oil dependent country in Latin America. Ecuador lost only $1.3 \%$ of GDP and after a year returned to pre-crisis levels of growth. ${ }^{1}$ In fact, in the midst of global recession and severe austerity in Europe and the US, in 2008 the Ecuadorean government of Rafael Correa Delgado embarked upon an ambitious economic development plan termed the Transformation of the Productive Matrix. The plan is designed to confront the country's historic dependence upon the export of un-processed natural resources, low levels of productivity and technological development, high levels of informality and social exclusion and, above all, a structural dependence upon foreign exchange earnings from oil exports. Much of the project has been inspired by the Economic Commission for Latin America's (ECLAC) promotion 
of 'Structural Change for Equality', based upon development policies derived from the school of economic thinking known as neo-structuralism. ${ }^{2}$ Specifically, ECLAC has provided a contemporary paradigm in which natural resource income can be thought of as the bridge towards 'knowledge-based' economic development, where a source of 'genuine' productivity (enhancing technical progress) is sought over 'spurious' ones' (reduction of wages, exchange rate advantages, exploitation of natural resources). In Ecuador this has been translated into a development program in which resource extraction has to be intensified in the short term in order to support the aims of transitioning to a 'knowledge-based' economy in the longer term. ${ }^{3}$ In 2014 , the Executive Director of ECLAC, Alicia Barcena, lauded the use of oil revenues to drive public investment, exclaiming that Ecuador has 'taken the bull by the horns and managed to diversify its economy.'4

This intensification of state-led natural resource exploitation has led some scholars to label state intervention as 'neo-extractivism' that leads to ecological destruction and ultimately the reproduction of the 'resource curse'. ${ }^{5}$ In contrast, other scholars see the progressive use of natural resource income as the way in which 'postneoliberal' regimes in Latin America can reduce poverty, improve welfare and chart their own paths within the global economy. ${ }^{6}$ Whilst usefully drawing our attention to pressing social and ecological concerns and the politics of resource governance, this literature has had less to say about the relationship between natural resource rents and production. ${ }^{7}$ As a result it has not adequately dealt with the form taken by new industrial and technological development initiatives that have emerged in regimes where 'neoextractivism' or 'post-neoliberalism' are said to operate.

To fill this gap this paper draws upon the Marxian critique of political economy to offer a historically grounded and empirically informed rent-theoretical analysis of the 
policies designed to transform the productive matrix in Ecuador. We make the case that neostructuralism naturalizes both 'natural resources' and 'knowledge' as factors of production, thereby obscuring the social conditions, and global context, under which they enter the production process. The problematic upshot is that the revenues, or rents, from both are seen to exist in isolation, the former rebuked as an unearned gift of nature and the latter celebrated as the product of innovation and entrepreneurship. ${ }^{8} \mathrm{By}$ demonstrating that rent is not only a distributive category of economic surplus, but also a material relation of production that historically underpins specific and uneven processes of capital accumulation, we can account for the emergence and limits of development strategies in Ecuador that seek to harness 'knowledge' to wealth creation. We make this argument in reference to the failure of selective import substitution industrialisation (ISI) to expand the domestic scale of capital accumulation and the contradictions of targeting vanguard science and technology development strategies that are materially out of step with the needs and capacity of the domestic economy. The former relies upon the 'intelligent' targeting of state subsidies towards 'knowledgebased' local-value added production, yet this has been led mainly by small industrial capitals with low innovation and productive capacity. Whereas the latter sees 'immaterial' human knowledge as the locus of systematic competitiveness that can be realised through the construction of a new 'City of Knowledge' called Yachay. Although envisioned as a space of innovation and learning that can tap into Ecuador's main comparative advantage - its bio-diversity, the bid to competitively attract global bio-tech capital points toward the institutionalisation of private property rights around the very 'knowledge' that is identified as the route towards an egalitarian modernity.

The first part of the paper critically situates the developmental reading of natural resource income offered by ECLAC and argues that neostructuralism suffers from an 
under-theorisation of natural resource rents. In the second part of the paper we explain the Marxian concept of ground-rent through a value-theoretical lens of uneven geographical development in Latin America. Section three draws upon Juan Iñigo Carrera's work on the relationship between ground-rent and capital accumulation in Latin America in order to situate Ecuador's three major primary export booms in historical context. In drawing attention to the role of small industrial capitals, we account for the specifically restricted form of industrial and technological development in Ecuador. Section four puts this approach to work to argue how, and why, the neostructuralist policies designed to transform the productive matrix in Ecuador are reproducing specifically restricted, rent-dependent, forms of capital accumulation. ${ }^{9}$ In the conclusion we draw the different strands of the argument together to show how our rent-theoretical critique can illuminate the contradictory relationship between rents, knowledge and production in Ecuador's TPM.

\section{Neostructuralism and the resource curse}

Neostructuralism has its intellectual roots in the reforms that ECLAC put in place to accommodate the structuralist tradition to a globalized world. ${ }^{10}$ Although too heterogeneous to be called a paradigm, the different strands of neostructuralism have a common objective to re-conceptualize the relations between the state, economy and society, that is to recouple economic growth with social equity and look for pragmatic synergies within globalization that can generate 'systematic competitiveness' ${ }^{11}$ In this context ECLAC has modified the structuralist plan for industrialisation based upon income from natural resources, which, pace the classic texts of Prebisch and Singer, are no longer seen as the cause of deteriorating terms of trade or as a barrier to economic diversification. ${ }^{12}$ Rather, natural resource revenues can stimulate 'long term development if they are used for structural change in a way that creates new 
comparative advantages derived from knowledge-based activities that do not deplete in time and provide growing returns'. ${ }^{13}$ 'Knowledge-based' activities are repeatedly, and vaguely, cited as those which are intensive in technology and able to stimulate 'Schumpeterian efficiency', in which rents from innovation drive productivity enhancing activities across the economy. ${ }^{14}$

For this approach natural resources are neither a curse or a blessing, and nor are they to be viewed in neoliberal terms as being equivalent to any other factor of production within the logic of comparative advantage. ${ }^{15}$ Rather, institutions and public policies have a role to play in the productive re-allocation of natural resource income, but in a way that does not repeat the so-called errors of the first attempt at ISI. This conceptualization of structural change on the basis of natural resource income is pitted against the now well established 'resource curse' literature, which correlates abundant natural resources with a variety of social, economic and political ills. ${ }^{16}$ However, a closer inspection of the recent ECLAC literature reveals the reproduction of the economic (neoclassical) and governance (public choice theory) tenets of the resource curse theories ${ }^{17}$ For instance, macroeconomic problems such as the appreciation of the exchange rate, the re-allocation of capital to non-tradable sectors and rising costs of capital and labour are un-problematically explained with appeal to the 'Dutch Disease's' analysis of the effects of windfall revenues. ${ }^{18}$ As such, the appropriate response according to ECLAC should take the form of macroeconomic policies that modify relative prices in favour of tradable productive activities, but with a real exchange rate that is neither under nor overvalued so as to reflect true 'systematic competitiveness' within a balanced current account. ${ }^{19}$ This technical reading, in which the state can intervene to control price signals, is also seen as the correct way to reorientate patterns of 'rent seeking' towards investment in productivity enhancing, 
'knowledge-based' activities led by Schumpeterian efficiency. ${ }^{20}$

This is symptomatic of ECLAC's neostructuralism which, according to one critic, problematically assumes that the negative consequences of utility maximizing agents' behavior can be corrected by state policy, but in doing so 'excises fundamental analytical categories dealing with power relations that constitute the realm of labourcapital relations, the increasingly transnationalised circuits of accumulation of capital, and the capital accumulation-social reproduction nexus. ${ }^{21}$ Therefore, although the neostructuralist approach does not strictly share the neoclassical perspective of rents as always implying inefficiency in an otherwise perfectly competitive market, ${ }^{22}$ it does assume that resource income distorts the allocation of capital and labour thus requiring state intervention to correct market imperfections. ${ }^{23}$ In fact, very little attempt is made to theorise resource income as rents, nor elaborate their relationship with capital accumulation or 'knowledge-based' activity. ${ }^{24}$ Rather than an unconscious underdevelopment of these concepts this can be identified as the result of 'systematic choices', especially when we acknowledge that detaching rent theory from its core in classical political economy was a defining characteristic of neoclassical economics. ${ }^{25}$ This type of reading of resource rents in one-sided in so far as it wrenches 'the theory of rent from its counterpart in the labour theory of value', and in doing so it severs the link between the historical development processes (industrial production and natural resource exports) that internally unite the global north and global south. ${ }^{26}$ In this vein of critique, the following section offers a Marxian reading of the global relations between rent and production, seen from the perspective of uneven geographical development in Latin America. 


\section{Rents, value and uneven geographical development}

One of the distinguishing historical features of capitalism is that social labour is carried out in a private and independent form and that the organization of productive activity is achieved through the exchange of commodities. ${ }^{27}$ It is through the process of exchange - mediated by competition among producers in a sector - that the socially necessary labour time required to produce a commodity is revealed to individual capitals which, post festum, establishes the normal or average method of production within a sector. As self-expanding value, based upon the exploitation of labour in production, capital will tend to flow to those sectors that offer the highest returns through the formation of the general rate of profit. ${ }^{28}$ This results in the uneven development of the productive forces within and across branches of production as capitals struggle to reproduce their social existence under the conditions of competition and the demands to produce below or at the social average in cost terms. ${ }^{29}$ This competitive, private and independent process of production is spatially expressed through the dialectic of differentiation and equalization, ${ }^{30}$ as the tendential equalization of average rates of profit across different branches of global industry takes concrete form in fragmented national processes of capital accumulation through the international division of labour. ${ }^{31}$

The fragmentation of this process in Latin America has been historically marked by territorial subsumption to global capital through the production of agricultural and mining commodities for the world market. ${ }^{32}$ Indeed, under capitalism the appropriation of nature occurs for the first time at a world scale and 'to the degree that natural resources are unevenly distributed so a certain kind of uneven geographical development results built around conditions of, say, agricultural productivity or the presence of oil reserves' ${ }^{33}$ This regional insertion of Latin America into the 'classical' international division of labour played a specific role in the development of global 
industrial capitalism. By cheapening the means of subsistence and reducing the value of labour power in the new industrial centres of the North Atlantic region, the total social capital experienced an increase in both labour productivity and the rate of surplus value production. ${ }^{34}$ Yet, in order to gain access to non-renewable natural resources attached to such portions of land under conditions of post-independence private ownership, global capital had to cede a portion of surplus-value to the landlord classes in Latin America. The resulting income for the landowner 'is known as ground-rent irrespective of whether it is paid for agricultural lands, building land, mines, fisheries or forests'. ${ }^{35} \mathrm{In}$ this way, although the supply of cheap raw materials increases industrial productivity and the rate of global capital accumulation, the portion of surplus value paid as groundrent represents a deduction from the total social capital accumulated. This renttheoretical perspective can be used to see how the production of both nature and space within the global geography of capitalism 'lies at the heart of uneven development'. ${ }^{36}$

For instance, this analysis implies that ground-rent forms part of the market price of primary goods, because in contrast with industrial commodities - whose market price is determined by the average conditions of production within a sector - the price of primary commodities in the world market is determined by the marginal producer, that is, the least fertile lands for which there is solvent demand. ${ }^{37}$ As a result, capital that operates on the most favourable and irreproducible lands will experience higher levels of productivity and lower production costs. However, competition among capital to access these lands will increase their rental price which permits the landowner to capture extraordinary profits - capitalized in the land price as a stream of rents. ${ }^{38}$ This revenue takes the form of differential rent, based upon the monopoly over differential natural conditions of production. ${ }^{39}$ And to the extent that the commodity is consumed overseas - such as oil - the surplus value that forms part of the ground rent comes from 
the workers and capitals purchasing the commodity in the importing countries. ${ }^{40}$

This line of argument obviously runs counter to those classic accounts that explain 'the development of underdevelopment' and 'dependency' in Latin America through the identification of the flow of surplus-value in the opposite direction, more recently re-invoked under the name of 'imperialist rent'. ${ }^{41}$ We differ from these approaches in that we argue that the process of capitalist development is essentially global in content and national only in its form of realization. ${ }^{42}$ This is relevant because it focuses our attention on the fact that the total value that enters into national spheres of accumulation in exchange for the export of primary commodities is greater than their costs of production (including normal profits):

'in connection with differential rent in general, it should be noted that the market value is always above the total production price for the overall quantity produced ... This is determination by a market value brought about by competition that produces a false social value. ${ }^{43}$

This means that in their specific determination as a source of cheap raw materials within the uneven development of global capitalism, Latin American countries - although to differing magnitudes - have historically been constituted by inflows of what Marx termed 'false social value' as the material basis for a class of landowners. ${ }^{44}$ Of course, these international inflows are not an isolated one-way process as capital has also been re-circulated out of Latin America through interest, profit and rents. For example, Latin America societies have historically used ground-rent to pay for external public debt borrowed at extraordinarily high interest rates; during ISI foreign capital was attracted to invest in these national spaces to take advantage of fiscal incentives and the chance to valorise obsolete technology in protected internal markets and remit profits abroad; and finally, ground-rent was used to pay for access to foreign technology (although outdated 
in world market terms) protected by licences and patents which permitted a short, but rapid, phase of capital intensive industrial growth. ${ }^{45}$ It is these processes of inflows and outflows of capital that can be used to illuminate the dialectical relationship between ground-rent, production and 'knowledge,' thereby demonstrating how ground-rent forms part of the regional unfolding of uneven geographical development in Latin America.

From this perspective the 'classical' international division was never simply about the polarization of an industrialised 'core' and 'dependent' periphery, the latter restricted to the role of supplier of raw materials and staple foods. ${ }^{46}$ Rather, there was a specific process of accumulation whereby industrial capital within the 'periphery,' although at a reduced scale, was able to valorize through the appropriation of inflows of ground-rent; a process which today also points towards the continuation of elements of the 'classical' within the 'new international division of labour' ${ }^{47}$ As we develop further in the following sections, whereas the former rests firmly on the continued inflows of ground-rent and their transfer to domestic markets, the latter has come about as part of the expanded global production of relative surplus value through new forms of 'knowledge' intensive large scale industry and the geographical separation of the 'mental' and 'manual' along global commodity chains. ${ }^{48}$ This calls further attention to the problematic idea that natural resource revenues, given their external origin and the structural constraint they place on the domestic scale of capital accumulation, can be used to pursue national forms of 'systematic competitiveness' based upon 'knowledge' led' industrial upgrading.

The following section employs this perspective to understand the dynamics and effects of the three main historical commodity export booms in Ecuador. This allows us to connect past and present windfalls through a rent-theoretical reading that takes 
seriously the formation of social classes, firms and technology in relation to specific processes of capital accumulation.

\section{Ecuador and the accumulation of capital through the appropriation of ground rent}

Ecuador, where primary commodities have historically made up over $90 \%$ of exports, is a paradigmatic expression of the form of uneven development of capitalism outlined above. ${ }^{49}$ Inflows of differential ground-rent have been a perennial feature of the development of Ecuadorean capitalism, marked by three phases in particular where a single commodity dominated exports: successively, cacao (1895-1920), banana (19481970), and oil (1972-1983). These inflows consolidated the economic power of a financial-commercial-rentier elite composed of a small landlord class, both in their original role as agro-exporters and subsequently through their participation in industrial capital. ${ }^{50}$ Although to differing degrees, each phase of resource centred development has been marked by the state's intervention into the inflows of differential rents and their concomitant transfer to the rest of the economy which resulted in the establishment of specific conditions for the circulation and accumulation of capital in the national economy. ${ }^{51}$

During both the cacao and banana booms high international prices, the magnitude of exports and inflows of foreign exchange led to the appreciation of the national currency and concomitant import booms. ${ }^{52}$ A national currency is overvalued when its capacity to represent social wealth is greater in the domestic than in the world market - i.e. than its real purchasing power. ${ }^{53}$ This overvaluation, which is never an automatic effect of windfall but always a state policy, ${ }^{54}$ forces exporters to sell foreign exchange earned in global markets below its value, the loss of a fraction of the export 
price can be sustained because 'a surplus profit - ground rent in the case of primary commodities - must materialized in the price of the exported goods ${ }^{55}$. Subsequently this foreign currency can be sold below its value to industrial capital for the import of machinery and raw materials, thus indirectly transferring ground rent to the domestic economy. ${ }^{56}$ Equally, the state can use targeted imports taxes to recover a portion of the ground-rent from importers benefitting from cheap foreign exchange. Another more direct policy through which the state could divert a portion of the rent away from the landlord's pockets and into the state coffers is export taxes ${ }^{57}$ Levying specific taxes directly on the primary commodity in question allows the state to recover a portion of the ground-rent, but not touching the normal profit of capital, from those agro-exporters participating in the circulation of these commodities to the world market. ${ }^{58}$ This mechanism, known as export retention, means that ground rent passes directly into the hands of the state, which can later be transferred to the domestic economy if the state uses this additional social wealth to underwrite subsidies, public lending at negative real interest rates, tax exemption and price controls etc. ${ }^{59}$ It is in this way that import substitution strategies are financed, and limited, by the magnitude of ground-rent available for appropriation.

To different extents these policies were observable during both the cacao and banana booms as import and export taxes were used to generate state resources and transfer ground-rent to industrial capital. ${ }^{60}$ However during the cacao period such public policies, led by an essentially oligarchic state under the banner of the liberal party, were extremely incipient and ground-rent was either remitted abroad in the form of profits to English and German stockholders or dedicated to the luxury consumption of landed classes with minimal expansion or diversification of the internal market. ${ }^{61}$ It was during the banana period when these policies would take a conscious institutional form through 
an incipient ISI process. In 1954 the National Board of Planning and Economic Coordination was founded which passed the Law of Industrial Promotion in 1957, exonerating the import capital goods from taxation along with other considerable tax exemptions under the ECLAC doctrine of Raul Prebisch. ${ }^{62}$ When the state turned to policies such as tariff protection, direct state investment, credit at fixed negative rates, tax rebates and preferential import licenses manufacturing industry for the internal market became the leading growth sector. Yet these same incentives would go on to foment a national industrial sector with strong oligopolistic characteristics, as agroexporter groups, both from the coast and the Sierra, diversified their holdings into protected industry such as textiles, foodstuffs and beverages dominated by small capitals, often in partnership with fragments of international capital. ${ }^{63}$ Unlike normal capitals that sell their products in the world, small capitals are those which do not reach the scale or level productivity necessary to valorise outside of protected domestic spheres. $^{64}$

Industrialisation initiatives were revamped and intensified in the third period of oil-financed development, when the main appropriator of ground-rent became the Ecuadorean state and the magnitude of differential rents increased dramatically. Indeed, the differentia specifica of oil landlord states derive from the materiality of mineral visá-vis agricultural production. As opposed to individual agrarian landowners, whose resource commodity is reproducible and temporally dependent upon each production cycle, mining landowners 'can sit on their natural resources' until the conditions to appropriate a larger mass of ground-rent are more favourable. ${ }^{65}$ Therefore, mining landowners, when organised as a class at the world market level in organisations such as the Organisation of Petroleum Exporting Countries (OPEC), will have more bargaining power vis-à-vis industrial capital than agrarian ones, making the rents of oil landlord 
states relatively larger. This was the fortuitous position that Ecuador found itself when two years after joining OPEC as an oil exporter in 1972, oil prices quadrupled creating a foreign exchange bonanza 'that sustained an average GDP growth rate of $6.3 \%$ a year during $1975-80^{\prime}$ and crucially positioned the state as the dominant monopoly power over the appropriation and distribution of ground-rent. ${ }^{66}$

By 1974 oil income reached 1.16 USD billion (two thirds of income from exports in that year). The state negotiated contracts with oil companies that insured the inflow of new resources to undertake infrastructure programs, the expansion of education and health as well as generous import substitution policies and agricultural modernization. ${ }^{67}$ Under tariff protection and generous subsidies to import capital goods, manufacturing production grew by an annual $10 \%$ in activities that were intensive in capital and energy and not labour. Unable to compete in the world market, only those capitals that open and close their cycle of valorisation within the national economy can appropriate ground-rent through these mechanisms, effectively sealing off the domestic market. ${ }^{68}$ This manifested itself in the further proliferation of small industrial capitals (some within chains of fragments of large international capitals) that only managed to take advantage of the "easy" stage of ISI, that is to say "substituting the import of basic and non-durable consumer goods without generating higher levels of inter-industrial integration towards the production of intermediate goods. ${ }^{69}$ It is for this reason that industrialisation in Ecuador was characterised by obsolete technology, and in today's ECLAC parlance low in knowledge intensity. Therefore, it is here that we can historically locate the relationship between ground-rent, production and 'knowledge' and highlight that the latter is not simply a factor of production, but a social process historically and institutionally embedded in uneven and differentiated labour processes, firms and forms of technology. 
Throughout Ecuador's strongest period of industrial expansion, the dominant classes maintained their power intact both in the watering down of any substantial agrarian reform and increasing their control over incipient manufacturing sectors. ${ }^{70}$ Thus rather than the emergence of the industrial bourgeoisie as an autonomous faction of capital, we see the subsumption of industrial manufacturing within the interests of the financial-commercial-rentier elite. ${ }^{71}$ The export of non-ground rent bearing commodities (everything except oil, bananas, shrimps and cacao) were negligible for the majority of the oil boom period, as industrial capital valorized in the domestic market on the back of state mediated ground-rent transfers. The jump in public spending was accompanied by a decline in fiscal revenue, provoking deficits in the balance of payments which was covered by debt from foreign banks eager to recycle petrodollars in the late 1970s. ${ }^{72}$ As was the case across Latin America, the fall in primary commodity prices and a hike in global interest rates in 1979 pushed Ecuador into a period of crisis and structural adjustment.

From the rent-theoretical perspective developed here it is important to note that when ground-rent ceased to grow at the pace required to compensate for the difference between local and world market levels of productivity, capital accumulation was sustained by: the payment of labour-power below its value; inflows of foreign public debt; exchange rate devaluation; and the selective protection of industrial sectors such as automobiles. ${ }^{73}$ During the so-called 'lost decade' of the 1980 s, the limited inflow of ground-rent saw the contraction of industry and the downsizing of the state as privatizations were enacted and wages were pushed down under trade liberalization policies. These structural adjustment strategies confined and deepened Ecuador's traditional role as a provider of natural resources throughout the so-called 'long night' of neoliberal structural adjustment. This was the scenario in which the oil sector was 
opened to foreign investment and the state reduced its participation, giving up $80 \%$ of oil royalties to private capital. ${ }^{74}$ In addition, following the financial crisis of the late 1990s and the adoption of the dollar as the national currency, the Fund for the Stablilisation of Social and Productive Investment and the Reduction of Public Debt (FEIRIP) was created which committed $70 \%$ of oil revenue to the payment of external debt. ${ }^{75}$ It was only in 2005 during the upswing in global commodity prices that the then Finance Minister, Rafael Correa, began reforming the FEIRIP and the state began to reassert its control over the recovery of ground-rent.

\section{Transforming the productive matrix in Ecuador: the political economy of neostructuralism}

Commentators agree that from 2006 to 2013 annual growth of $4.2 \%$ in Ecuador was achieved on the back of a number of conjunctural factors that have signalled a deepening of the primary export model. ${ }^{76}$ Principally Ecuador benefitted from elevated international oil prices, as shown by the fact that the government of Rafael Correa Delgado (2006-present) received three times the amount of revenue from oil exports than any other Ecuadorean government in history. State royalties from the monopoly control over oil have been further boosted by new operating contracts (with $99 \%$ of profits going to the state) and the construction of a new heavy crude pipeline in 2004 which increased annual output by 53 million barrels. ${ }^{77}$ Ecuador would also benefit from a period of low interest rates in international capital markets and the favourable renegotiation of foreign debt, meaning the majority of oil revenues were no longer diverted to external liabilities. ${ }^{78}$ In addition, when the dollar was undervalued on international markets between 2007 and 2008, Ecuador benefitted from the rare coinciding occurrence of both high prices for natural resource exports and a competitive exchange rate (under-valued dollar), permitting both the agro-export elite and the state 
to appropriate an elevated magnitude of differential rents under a seemingly harmonious cycle of economic expansion.

This dual rentier political economy can be seen in expanded state spending with considerable levels of public and social investment, alongside unprecedented levels of wealth concentration amongst the traditional financial-commercial-rentier elite. Similar to the processes outlined above, an oligopolistic capitalist class have both fed internal demand with expanded imports, but also taken advantage of selective ISI policies for domestic production and consumption financed by an oligopolistic banking sector. ${ }^{79}$ In this way traditional elites have managed to benefit from both agrarian exports and monopoly control over the internal market, where oil financed state spending has increased internal demand and consumption. This led Correa to recognize that "we have not been able to change the model of accumulation drastically. Before changing it, we are basically improving things with the same model of accumulation, because it is not our desire to persecute the rich, but it is our intention to have a more just and equal society. ${ }^{80}$

It is in this structural context that we can locate the 'knowledge-based' policies designed to transform the productive matrix. These can be divided into 'selective ISI strategies' that aim to increase domestic production and 'vanguard' initiatives that take their inspiration from the perceived importance of modern science, research and technology. The former depicts 'knowledge-based' development as the production of material goods with some form of local value-added, whereas the latter is based upon a vision of 'immaterial' human knowledge that can drive future revolutionary industries such as biotechnology. ${ }^{81}$ By taking into account the social conditions under which both forms of 'knowledge' enter the production process and their relations with the above outlined dialectic of inflows and outflows of ground-rent, we can unpack the limits and 
dynamics of the project to 'Transform the Productive Matrix'.

The architects of the transformation of the productive matrix recognise that a dependence upon oil revenue, both in terms of volatile prices and resource depletion (exhaustion of oil reserves by 2030), is unsustainable for a dollarized economy without the capacity to print money or devalue. In 2013 the non-oil trade deficit reached US\$9 billion (9.7\% GDP) and the overall trade deficit reached USD $\$ 1.088$ billion which means that, in the main, imports were financed by oil ground-rent. Moreover, dollarization means that Ecuador's de facto national currency is on parity with its capacity to represent social wealth as its purchasing power is the same in domestic and international markets. Along with tending to incentivize imports, ${ }^{82}$ and reducing the competitiveness of manufacturing exports, this has eliminated the possibility of using the overvaluation of the exchange rate as the policy mechanism to transfer ground-rent. In the absence of this mechanism to influence relative prices and therefore competitiveness, the state turned to sectoral policies to support, finance and protect national production. ${ }^{83}$

Sectoral policies are organised by the Committee for External Trade (COMEX) through an annual resolution designed to substitute imports and protect the production of capital goods in the internal market. In 2013, Resolution 116 of COMEX limited 293 imports through quality control restrictions. ${ }^{84}$ At the same time the Ministry and Industries and Productivity (MIPRO) signed firm based agreements with the objective of reducing imports by a value of USD\$849 million. ${ }^{85}$ In 2014 a reported 679 agreements were signed with 905 companies that generated savings of USD\$1,726 million and saw a reduction of USD $\$ 163$ million in the non-oil trade deficit. ${ }^{86}$ These import substitution and tariff policies offer a de facto currency devaluation by making imports more expensive and thereby incentivizing domestic production. ${ }^{87}$ For example, 
MIPRO struck specific deals with rubber, ceramics, textile, toys, cosmetics, car parts and electrical goods companies for selective import substitution, to avoid the above outlined pitfalls of traditional blanket ISI strategies. However, in the context of added pressures to safeguard dollarization, it becomes analytically difficult to separate initiatives designed to limit the exit of foreign exchange from those genuinely targeted at productivity enhancing development. For instance, it has been pointed out that the foreign exchange savings of 2013 (USD \$ 1.7 billion) were less influenced by import substitution than by the high prices reached by the export of shrimps, bananas and cacao. And with the fall in primary commodity prices that started in mid-2014 extra pressure has been transmitted to the balance of payments, leading to the introduction of further tariff barriers designed solely to protect dollarization. ${ }^{88}$

These limits can be seen in another initiative to support the manufacturing of induction ovens. According to the Correa administration, the incentivized transition to new technologically efficient household electric induction cookers will allow the state to remove socially regressive gas subsidies which represent an annual cost of USD $\$ 1$ billion; renewable energy from new dams will drive down the costs of electricity; and the demand for subsidized induction cookers will create value added industrial manufacturing (under tariff protection). ${ }^{89}$ This is a clear example of how ECLCAC's targeted industrial policies were put to work to transfer natural resource income into quality job creation based upon productivity enhancing and value added sectors. ${ }^{90}$ However, despite subsidies of USD \$2.4 million to stimulate consumption, the sectoral incentives put in place to stimulate the production of 3.5 million induction ovens by 2016 have only partially been taken up by Ecuadorean white goods manufacturers. Manufacturers complained of late payment of government subsidises for their inability to raise levels of production, even though they claimed to have the installed capacity to 
meet all national demand. ${ }^{91}$ Nevertheless, in the absence of an increase in national supply, in December 2014 the government removed VAT and tariff barriers to the import of induction cookers with Correa stating 'we don't depend on the will of national producers, if they show they want to do it we will stop the imports...they have failed us in these months'. ${ }^{92}$

Despite this moral and political castigation, such policy failure cannot be reduced to the failings of individual capitalists. Rather, we believe, this demonstrates a broader underlying limit to selective industrial incentives in Ecuador where capital either lacks the scale and productive capacity or has looked to take advantage of subsidies in a way that does not require new innovation nor risky investments, relying instead upon reproducing 'easy' forms of ISI (toys, bicycles, auto-assembly etc.) reminiscent of the 1970s. ${ }^{93}$ This illustrates how small capitals have accumulated capital through the appropriation of ground rent (mediated by sectoral policies) in isolation from the pressure to innovate and compete in a way that would spread knowledge-based 'Schumpeterian efficiency' across the economy. ${ }^{94}$ Thus we can see that the model endorsed by ECLAC - in which innovation and entrepreneurship are rewarded by Schumpeterian rents (essentially above average profits for firms), the competition over which drives technological change and social efficiency - is far removed from the material dynamics of capital accumulation in Ecuador. Instead, the 'extra-economic' institutional policies of resource allocation have not led to the creation new Schumpeterian rents but are actually the way in which small capitals have accumulated capital through the appropriation of ground-rent.

The limited avenues for selective, but traditional, industrialisation, in part explains the paradoxical attractiveness of the 'vanguard knowledge-based' economy to policy makers. Our primary interviews point to three main justifications: First, given 
that dollarization restricts and limits the competitiveness of exports, to the extent that a small set of primary commodities (oil, bananas, coffee, cacao, and shrimps) are sold on the world market, Ecuador must find new products, international market niches and forms of innovation for competitive export promotion. ${ }^{95}$ Second, the creation of new 'knowledge-based' sectors is attractive in terms of human capital updating and the investment in so called infinite resources (intellectual labour). Third, creating new spaces of research and investigation can attract foreign direct investment (creating new sources of foreign exchange), and channel resources into comparative advantages that may exist from the country's biodiversity, but in a way that can create not only primary rents but the national value-added processing of new genetic material, drugs etc.

Heading this strategy is the The Knowledge City Yachay (Yachay: Ciudad del Conocimiento), under construction in the rural municipality of San Urcuqui 180 kilometres north of Quito. Under consultancy guidance from the Korean company behind one of the most successful free economic zones (FEZs) in Northeast Asia (Incheon Free Economic Zone - IFEZ), Yachay has been denominated the first Special Zone of Economic Development (Zona Especial de Desarrollo Económico - ZEDE), a delimited tax-free territory with fiscal incentives to strengthen productive investment. ${ }^{96}$ A known admirer of the East Asian Tiger's record of rapid industrialisation, the hiring of the IFEZ came out of Correa's tour of South Korea in 2010 and the government has even sought to attract investment by promoting the idea of Ecuador as the 'Latin America Jaguar' ${ }^{97}$ The Yachay project started in earnest in May 2012 under the initiative of the National Secretary for Higher Education, Science and Technology (SENESCYT) and later in partnership with the National Secretary of Planning and Development (SENPLADES). In 2013, the public company Yachay EP was created by executive decree - with an initial budget reported to be around a billion US dollars - to 
manage the design and execution of the urban master plan and liberate its management from the complexity of state bureaucracy. ${ }^{98}$ As Ecuador's flagship project for hi-tech knowledge-based development and the perceived root towards 'systematic competitiveness', Yachay underpins the government's (circular) reasoning that extractivism (mining and oil exploitation) has to be intensified in the short term in order to finance the escape from an extractivist economy. For example, during the inauguration of the construction in May 2014, framing the initiative against the countries pernicious dependence upon oil, Correa placed special emphasis upon technology and innovation and remarked that, "here is being born the new homeland, here we are overcoming the extractivist economy in a human and sovereign form". Described as the most important development project in Ecuador's history Yachay, seeks to replicate the 'triple helix' design of global science parks and envisions bioknowledge as a potential comparative advantage that can create one of the most important centres of applied research in the region. ${ }^{99}$ According the National Plan for Buen Vivir,

Ecuador's main comparative advantage is its biodiversity and, unquestionably, its main competitive advantage would be to acquire the knowledge of the best ways to make use of this biodiversity, through its conservation and by building national industries related to bio- and nanotechnology. ${ }^{100}$

At the centre of the project sits a new publically funded Yachay University, designed to be the launchpad for genetic prospecting in the Ecuadorean Amazon and the fulcrum of a new world leading pole of scientific research and development. Termed 'Republican Bio-Socialism', according to SENESCYT, this can lead Ecuador to .... a different economy, in which science, technology, innovation and knowledge permit us to transition from an economy of finite resources - that is to say, the production and exportation of natural resources - towards the scientific, economic 
and industrial appropriation of these resources, to reach an economy of infinite resources.

The hope of policy makers is that a new Code for the Social Economy of Knowledge can create a governance framework for intellectual property outside the logic of patents and private property, the institutional basis of rents in high-tech industries. ${ }^{101}$ The chief intellectual architect of this vision is the General Secretary of SENESCYT Rene Ramirez, who calls for an open and public form of knowledge production through 'Great Productive Agreements' between the state, private sector, academia and civil society. ${ }^{102}$ Railing against the 'hyper-privatisation' of knowledge and 'neo-dependency' on 'western science' the state is seen as the arbiter between a 'plurality of forms of property' to ensure the 'highest form of democratisation of the benefits and opportunities of knowledge'. ${ }^{103}$ Yet these ideological platitudes for a legislative route to an economy of 'infinite resources' sit ill at ease with the creation of a free trade zone which, according to official promotional documents, seeks to attract global bio-tech capital such as Pfizer and AstraZeneca. As is well known, the very business models of these companies revolve around the extension and enforcement of intellectual property monopolies. ${ }^{104}$ In this global industry patents function in the same manner as the above outlined private monopoly over non-reproducible natural resources, by enclosing 'knowledge' the owner can create artificial scarcity and charge a rent for access to the licence, code or genetic material.

Here we can see the paradox at the root of the hope to exploit their monopoly ownership over non-reproducible natural resources (oil and mining) in a way that cross subsidises new bio-technology free from the contradictions of rentier capital accumulation. What this idealized notion of 'knowledge-based' development naively underestimates is the extent to which novel forms of intellectual and scientific labor 
have come about as part of the global intensification of the production of relative surplus value and the deepening of 'knowledge' and 'technology' as central axes of accumulation'. ${ }^{105}$ This has seen global capital relocate production to spaces that offer the optimum combination of cost and productivity, and the fact that this global form of production has come to be associated with the 'knowledge economy' is because, in essence, it is the contemporary mode in which capitalist development is driving (automation-based) technological change. Moreover, when knowledge intensive code, machinery, drugs or genetic material falls under licence and patents they can form a stream of rents for the owner of the monopoly over the intellectual property, blocking the competitive equalisation of profit rates and, therefore, the long term efficiency enhancing impact of Schumpeterian rents. ${ }^{106}$

Thus below the shallow discourse, Yachay revolves around a mystification of 'knowledge-based' development as a technical exercise of combining the necessary factors of production - labour, capital, knowledge and land (bio-diversity) - in a dedicated free trade zone. Such a positivist 'conception of science, knowledge and technological progress' leads to what Vercellone et al have identified as 'the abstraction of the social relations' surrounding the control of such powers of production. ${ }^{107}$ As a result, strategies to link research and investigation to the actual productive matrix have an extremely embryonic, even incongruous, character; as investment in new Nano and Bio technologies currently lack a national industrial fabric with any demand for this technology. ${ }^{108}$ In this context Villavicencio has pointed out that the Schumpeterian logic of rent capture, in which new innovation drives economy wide efficiency, bears little resemblance to a national economy of small firms that tend to leave and enter the market with similar levels of outdated technology. ${ }^{109}$ 
As of 2016, Yachay EP had not managed to attract any significant investment, was embroiled in scandals around the parachuting in of 'northern' academics on large salaries and, with the precipitous fall in the oil price, was forced to seek a loan of US\$198 million from The Export Import Bank of China to continue the first phase of construction. ${ }^{110}$ Whilst riding high on the commodities boom Ecuador could rent finance ambitious schemes such as Yachay which Correa is loath to abandon, finding temporary respite in new debt. This illustrates the volatile dialectic between inflows and outflows of capital in the form of ground-rent and interest respectively which have historically limited grand development projects across Latin America. In this context, incentivizing foreign investment through the creation of tax-free 'bio-knowledge enclaves' with limited linkages to the national economy could paradoxically reproduce the kind of resource dependent export model of development from which the government is trying to escape. ${ }^{111}$

\section{Conclusion}

This paper has interrogated the relationship between rents, knowledge and production in Ecuador's state-led project to transform the productive matrix. We showed how an economy historically centred on the extraction of ground-rent is marked by, and embedded within, specific processes of capital accumulation which limit what can be realistically achieved by a state-led turn to a knowledge-based economy. As a result, we argued that 'knowledge' has fallen prey to the same under-theorization as its discursive opposite - 'natural resources'. By analytically identifying the social origins of rent, the paper highlighted how the export of natural resources and inflows of differential rents form part of the regional unfolding uneven geographical development in Latin America. Applying this to the historical development of capitalism in Ecuador we showed how transfers of ground-rent were historically mediated by a combination of state policies 
that protect and incentivize small capitals but, in doing so, create a structural dependence upon the magnitude of ground-rent available for appropriation.

Using this analysis to understand Ecuador's current policies to pursue 'knowledge-based' strategies, we were able to show that natural resource income and knowledge are not simply technical inputs, but historically and institutionally embedded in uneven and differentiated labour processes, firms and forms of technology. As such, the division between selective ISI and vanguard 'knowledge-based' strategies were shown to be the policy expression of neostructuralism's under-theorisation of rents. The former strategies were shown to reproduce easy forms of ISI, allowing small industrial capitals to accumulate through the appropriation of ground-rent in isolation from the kind of technological innovation that ostensibly leads to 'Schumpeterian efficiency'. In contrast, the latter strategies represented an abstraction from the social relations of production in Ecuador, as 'knowledge-based' development has been conceptualized as the functional outcome of taking advantage of immense bio-diversity through subsidized research, development and innovation. Perhaps most gravely, in the absence of national capitals linked to this state-led project (as occurred in other regions of rapid industrial development and technological updating, such as South East Asia), this potentially points towards outflows of ground-rent and natural resources through subsidized bio-knowledge enclaves to attract international capital as a competition strategy within the new international division of labour.

\footnotetext{
${ }^{1}$ Kay and Kozameh, Ecuador's Economy Since 2007.

${ }^{2}$ Bielschowsky. Sesenta años de la CEPAL, 97.

${ }^{3}$ PNBV, Plan Nacional del Buen Vivir, 2013-2017.

${ }^{4}$ Interview with Alicia Barcena, 'Cepal: "Necesitamos una economía más basada en el conocimiento", available at http://laprensa.peru.com/economia/noticia-cepalnecesitamos-economia-mas-basada-conocimiento-34862 accessed 09/01/2016.
} 
${ }^{5}$ See, respectively, Gudynas, 'Estado Compensador y Nuevos Extractivismos', 128; Bebbington and Bebbington, 'An Andean Avatar'..

${ }^{6}$ See for example, Muhr, '(Re)constructing Popular Power in Our America', 225.

7 See for example, Burchardt and Dietz, '(Neo-)extractivism', 468. Rosales, 'Going Underground', 1443.

${ }^{8}$ Schumpeter, Capitalism, Socialism and Democracy.

${ }^{9}$ The paper draws upon 10 in depth semi-structured interviews with members of the Inter-Institutional Committee for the Transformation of the Productive Matrix made up the Vice-Presidency and three principal Ministries: The Coordinating Ministry for Production, Employment and Competitiveness (MCPEC), The Ministry for Industries and Productivity (MIPRO) and The Ministry of Agriculture (MAGAP).

${ }^{10}$ Weyland, 'The Political Economy of Market Reform', 235.

${ }^{11}$ Leiva, 'Towards a Critique of Latin American Neostucturalism', 12.

${ }^{12}$ Prebisch, The Economic Development of Latin America; H Singer, 'The distribution of gains', 473.

${ }^{13}$ ECLAC, 'Cambio Estructural para la Igualdad', 33. This document was cited by various interviewees as the basis for the design of the TPM project.

${ }^{14}$ Ibid. There are 133 instances where 'knowledge' is cited, for indicative examples see: 31, 38, 66, 79, 85, 243.

${ }^{15}$ See for example, ECLAC, 'Cambio Estructural' p 103; and Bárcena and Prado, 'Neoestructuralismo y corrientes heterodoxas', 258.

${ }^{16}$ Sachs and Warner, 'The big push'; Auty, Resource Abundance and Economic

Development.

${ }^{17}$ See ECLAC, 'Cambio Estructural', 82.

${ }^{18}$ Corden and Neary, 'Booming sector', 835.

${ }^{19}$ See ECLAC, 'Cambio Estructural para la Igualdad', 79.

${ }^{20}$ Ibid, 65-6.

${ }^{21}$ Leiva, 'Towards a Critique', 8.

${ }^{22}$ Khan, 'Rents, Efficiency and Growth', Chap 1.

${ }^{23}$ See for instance, MCPE, 'Agenda de la Política Económica', 98.

${ }^{24}$ See, ECLAC 'Cambio Estructural', 252. It is difficult to encounter a specification of the social origin of rents beyond brief references to Ricardian scarcity rents.

${ }^{25}$ Grigera, 'Conspicuous Silences'; Bina, 'Some controversies', 82-111.

${ }^{26}$ Mcneish and O Logan, 'Rethinking responsibility', 1-46.

${ }^{27}$ See, Marx, Capital, 125; Iñigo Carrera, La Formación Económica.

${ }^{28}$ Marx, Capital Vol III, 994.

${ }^{29}$ Clarke, 'The Marxist Theory of Overaccumulation', 442.

${ }^{30}$ Harvey, The Limits to Capital; Smith, Uneven Development.

${ }^{31}$ Smith, Uneven Development; Burnham, 'Open Marxism', 221.

${ }^{32}$ Echeverria, Valor de Uso y Utopia, 40-41.

${ }^{33}$ Smith, Uneven Development, 71; Harvey, 'Notes towards a theory', 70.

${ }^{34}$ Grinberg and Starosta, 'From Global Capital Accumulation', 236.

${ }^{35}$ Marx, Capital Vol III, 755-56.

${ }^{36}$ Smith, Uneven Development, 187.

${ }^{37}$ Marx, Capital Vol III, 779-811.

${ }^{38}$ Ground-rent can take the social forms of Differential Rent (DR), Absolute Rent (AR) and Monopoly Rent (MR). DR springs from the monopoly over portions of the planet with differentially favorable natural conditions allowing lower production costs than those prevailing in the world's marginal lands for which there is solvent demand. AR derives from the simple monopoly over land and is paid even for the use of marginal 
lands and MR is the price imposed independently of production costs by the owner of a scarce resource. See K Marx, Capital Vol III: 779-87, 882-907, and 910. In this paper we are primarily concerned with differential rents that have their origin in other branches of social production.

${ }^{39}$ See Iñigo-Carrera, La Formación Económica, 12.

${ }^{40}$ Ibid, 15.

${ }^{41}$ See respectively, Frank, Latin America: Underdevelopment or Revolution;

Emmanuel, Unequal Exchange; Marini, Dialectica de la dependencia; Higginbottom, 'Imperialist Rent' in Practice and Theory' 23.

${ }^{42}$ Grinberg, 'The political economy' 171.

${ }^{43}$ Marx, Capital Vol III, 799-800.

${ }^{44} \mathrm{Ibid}$, in the same passage Marx clarifies that a false social value comes about when 'society pays too much for agricultural products' which 'is a minus for the realization of labour-time in agricultural production' but a 'plus for one portion of society, the landowners'; see also Laclau, 'Modos de producción; Iñigo Carrera, La Formación Económica.

${ }^{45}$ See Iñigo Carrera, El capital: razón histórica.

${ }^{46}$ Grinberg and Starosta 'The limits of studies'.

${ }^{47}$ Ibid. 773

${ }^{48}$ Huws, 'Defragmenting', 2.

${ }^{49}$ Larrea, 'Dolarización, crisis y pobreza en el Ecuador', 18 . This $90 \%$, made up by seven unprocessed goods: oil, coffee, cacao, shrimp, fish and flowers, is well above the regional average of $41 \%$.

${ }^{50}$ Chiriboga, 'Conformacion Historica del Regimen'.

${ }^{51}$ This analysis draws upon the framework pioneered by Iñigo-Carrera, La Formación Económica’ 2007.

${ }^{52}$ Hofman and Buitelaar, 'Ventajas comparativas extraordinarias y crecimiento' 149.

${ }^{53}$ Grinberg, 'The political economy', 457.

${ }^{54}$ See Saad-Fihlo and Weeks, 'Curses, Diseases and Other Resource Confusions'.

${ }^{55}$ Grinberg, 'The Political Economy, 456.

${ }^{56}$ Iñigo Carrera, La Formación Económica, for a detailed account of these mechanisms see pp 17-21.

${ }^{57}$ Ibid. 18

${ }^{58}$ Ibid. 19

${ }^{59}$ Ibid. 21

${ }^{60}$ A Hofman and R Buitelaar, 'Ventajas comparativas',

${ }^{61}$ M Chiriboga, Conformacion Historica. C Conaghan, Industrialists and the Reformist, 53-54

${ }^{62}$ C Conaghan, Restructuring Domination.

${ }^{63}$ Ibid, 45.

${ }^{64}$ Iñigo Carrera, El capital, 124.

${ }^{65}$ Iñigo-Carrera, La Formación Económica, 13-14.

${ }^{66}$ De Janvry et al, 'Politically Feasible and Equitable Adjustment' 1577.

${ }^{67}$ L North, 'Militares y Estado en Ecuado', 91.

${ }^{68}$ Iñigo-Carrera, La Formación Económica.

${ }^{69}$ Vos, 'Uso de las divisas' 235.

${ }^{70}$ Cueva, El Ecuador de 1960 a 1979.

${ }^{71}$ Báez, 'Algunos aspectos', 121.

72 Ibid.

${ }^{73}$ A De Janvry et al, 1991; C Larrea, 2004. 
${ }^{74}$ CDES, 'Comisión de Auditoría Integral'.

75 Ibid.

${ }^{76}$ Ospina, 'Ecuador: el nuevo período'; Unda, 'Modernización del capitalismo',30.

${ }^{77}$ Ruiz, La Alquimia de la Riqueza.

${ }^{78}$ Kay and Kozameh, 'Ecuador's Economy Since 2007'.

${ }^{79}$ Muñoz, 'Forma de Estado', 123.

80 "El desafío de Rafael Correa", (El Telégrafo 15 Jan 2012).

${ }^{81}$ Ramirez, 'La Virtud de los Comunes'.

${ }^{82}$ Hira and Dean, 'Distributional effects of dollarisation', 469.

83 These incentives are stipulated in the 2010 Organic Code for Investment and Production (Código Orgánico de la Produccion, Comercio e Inversiones - COIP).

${ }^{84}$ Although permissible under the Andean Communities' and WTO's trade rules which permit "General Exceptions" for actions taken to protect 'life, health and security', the more recent expansion of import restrictions (salvaguradias) to protect Ecuador's balance of payments, in response to currency devaluations by neighbouring Colombia and Peru, has led to denunciations of protectionism to the WTO (El Universo, 14 April 2015).

85 “29\% cayeron importaciones con la Resolución 116”, (El Comercio, 26 August 2014). [The import of products subject to new tariffs fell by 29\%].

${ }^{86}$ This strategy aimed to substitute USD\$ 396 million worth of imports, increase local purchases by USD \$ 132 million, and increase national production by USD \$ 475 million, create USD\$ 170 million of new investment and increase exports by USD\$268 million (Enlace Ciudadano No. 396).

${ }^{87}$ MCEP, 2011.

${ }^{88}$ P Ospina, 'Crisis y tendencias económicas'.

${ }^{89}$ Crespo, 'La sustitución de cocinas'.

${ }^{90}$ ECLAC, 'Cambio Estructural' p17.

91 'Industriales dicen que sí pueden proveer cocinas de inducción' [Industrialists say they can provide induction ovens] (El Universo, Friday 21 August 2015).

92 "Por Falta de apoyo de fabricantes, Rafael Correa anuncia importación de cocinas de inducción" [Due to lack of support from producers Correa announces the import of induction ovens] (El Universo, Economia, Sabado, 20 de diciembre, 2014).

${ }^{93}$ For example, taking advantage of ISI policies, the biggest toy manufacturer in the country, Plásticos Industriales PICA, grew by $35 \%$ in 2013 and reported sales of USD $\$ 77.5$ million, see "Travelina, la muñeca ecuatoriana más famosa cumple 16 años", (El Comercio, 30 October, 2014)

${ }^{94}$ ECLAC, 'Cambio Estructural' 17.

${ }^{95}$ See note 11.

${ }^{96}$ Incentives include: a 5\% reduction in income tax; 0\% VAT for the import of capital goods and primary material and VAT tax credits; the exemption from tariffs on foreign goods entering these zones; tax exemptions for foreign purchases that equals amortization of capital and interests that have been used to finance imports.

${ }^{97}$ Chávez, El estado, 17.

98 'Yachay, la universidad que proyecta formar a la élite científica de Ecuador, abre sus puertas' (Andes, 30 March 2014).

${ }_{99}$ PNBV, Plan Nacional del Buen Vivir, 321.

${ }^{100}$ Ibid

${ }^{101}$ R Ramirez, 'La Virtud de los Comunes'.

102 'Yachay el velo se descorre' [Yachay removing the veil] (Gestion Revista, May 23, 2013) 
103 The Organic Code for the Knowledge Economy, 8.

104 Yachay EP, "Expediente para constituir la ZEDE”, 88-9; See Zeller, 'From the gene to the globe, for an application of the rent theory to the bio-technology industry.

105 Grinberg and Starosta, 'The limits'.

106 Zeller 2008.

107 Vercellone et al. 'Theoretical Framework on the future'.

${ }^{108}$ P Ospina, 'Ecuador' 2013

${ }^{109}$ Villavicencio, Innovacion Matriz Productiva y Universidad, 116.

110 Andes (2016). "Ecuador suscribe crédito con China por 198 millones para la construcción de la Ciudad del Conocimiento Yachay", en

http://www.andes.info.ec/es/noticias/ecuador-suscribe-credito-china-198-millonesconstruccion-ciudad-conocimiento-yachay.html, febrero 25 de 2016 (última visita marzo 05 de 2016).

${ }^{111}$ Chávez, El estado del debate.

\section{Bibliography}

Auty, Richard. Resource Abundance and Economic Development. Oxford: Oxford University Press, 2001.

Báez, René. "Algunos aspectos de la evolución de la economía ecuatoriana (19791982)." Problemas del Desarrollo 15, 58 (1984).

Bárcena, Alicia and Antonio Prado. Neoestructuralismo y corrientes heterodoxas en América Latina y el Caribe a inicios del siglo XXI, [Neostructuralism and Heterdox Currents of Latin Americ and the Caribbean at the start of the 21st Century] Santiago: CEPAL, 2009.

Bebbington Anthony and Denise Bebbington, 'An Andean Avatar: Post-Neoliberal and Neoliberal Strategies for Securing the Unobtainable', New Political Economy, 16: 1 (2011): 131-145. DOI: 10.1080/13563461003789803

Bielschowsky, Ricardo. 'Sesenta años de la CEPAL: estructuralismo y neoestructuralismo', Revista Cepal, 97, (2009): 173-94.

Bina, Cyrus. "Some controversies in the development of rent theory: the nature of oil rent", Capital and Class 39 (1989): 82-111. DOI: 10.1177/030981688903900104 
Burchardt Hans-Jurgen and Kristina Dietz, '(Neo-)extractivism - a new challenge for development theory from Latin America', Third World Quarterly, 35, 3 (2014): 468-486. DOI: $10.1080 / 01436597.2014 .893488$

Burnham, Peter. "Open Marxism and Vulgar International Political Economy", Review of International Political Economy, 1, 2 (1994): 221-31.

CDES, ‘Comisión de Auditoría Integral del Crédito Público’ CAIC: Informe final, 2008.

Chávez, David. El estado del debate sobre desarrollo, extractivismo y acumulación de capital en el Ecuador, Quito: Centro de Derechos Economicos y Sociales, 2013.

Chiriboga, Manuel. "Conformacion Historica del Regimen Agroexportador de la Costa Ecuatoriana: La Plantacion Cacaotera”, Estudios Rurales Latinoamericanos, 1, 1, (1978): 111143.

Clarke, Simon. "The Marxist Theory of Overaccumulation and Crisis". Science \& Society, 5, 4, (1991): 442-67.

Conaghan, Catherine. Industrialists and the Reformist Interregnum: Dominant Class Behaviour and Ideology in Ecuador, 1972-1979 PhD Thesis, Yale University, 1983

Conaghan, Catherine. Restructuring domination: Industrialists and the state in Ecuador. University of Pittsburgh Press, 1988.

Corden, Max and Peter Neary. "Booming sector and de-industrialisation in a small open economy", The economic journal 92, 368, (1982). DOI: 10.2307/2232670

Crespo, Geraldo. "La sustitución de cocinas: una ruta para rebajar el subsidio Energía", Gestion, 231 (2014).

Cueva, Agustín. "El Ecuador de 1960 a 1979." Nueva Historia del Ecuador, 11 (1991).

ECLAC, 'Cambio Estructural para la Igualdad: Una visión integrada del desarrollo', [Structural Change for Equality: An Integrated Vision of Development] CEPAL, 2012, San Salvador.

Echeverria, Bolivar. Valor de Uso y Utopia [Use Value and Utopia] Siglo XXI: Buenos Aires, 1998.

Emmanuel, Arghiri. Unequal Exchange. London: New Left Books, 1972.

Frank, Andre Gunder. Latin America: Underdevelopment or Revolution. New York: Monthly Review Press, 1969.

Grinberg, Nicolas and Guido Starosta. "The limits of studies in comparative development of East Asia and Latin America: the case of land reform and agrarian policies", Third World Quarterly, 30, 4 (2009): 761-777. DOI:10.1080/01436590902867243

Grinberg, Nicolas. "The political economy of Brazilian (Latin American) and Korean (East Asian) comparative development: moving beyond nation-centred approaches". New Political Economy 18, 2 (2013): 171-197. DOI: 10.1080/13563467.2012.678823 
Grinberg, Nicolas and Guido Starosta. "From Global Capital Accumulation to Varieties of Centre-Leftism" Chap 8, in Crisis and Contradiction: Marxist Perspectives on Latin America. Edited by Susan J. Spronk and Jeffrey R. Webber, 2014: 236-272.

Grigera, Juan. "Conspicuous Silences: State and Class in Structuralist and Neostructuralist Thought", Chap 9 in Crisis and Contradiction: Marxist Perspectives on Latin America in the Global Political Economy, edited by Susan J. Spronk and Jeffrey R. Webber, Brill: Leiden Boston, (2014): 193-215.

Gudynas, Eduardo. "Estado Compensador y Nuevos Extractivismos: Las Ambivalencias del Progresismo Sudamericana”, Nueva Sociedad, 237, (2012): 128-146.

Harvey, David. The Limits to Capital London: Verso, 1982/2006.

Harvey, David. "Notes towards a theory of uneven geographical development", in Spaces of neoliberalization: towards a theory of uneven geographical development, Hettner Lecture: Franz Steiner Verlag, 2004.

Higginbottom, Andy. "Imperialist Rent' in Practice and Theory, Globalizations", 11: 1 (2014): 23-33. DOI:10.1080/14747731.2014.860321

Hira, Anil and James Dean, "Distributional effects of dollarisation: the Latin American case". Third World Quarterly, 25, 3, (2004): 461-482. DOI: 10.1080/0143659042000191384.

Hofman, Andre and Rudolf Buitelaar, "Ventajas comparativas extraordinarias y crecimiento a largo plazo: el caso del Ecuador", Revista de la CEPAL, 54, (1994): 149-166.

Huws, Ursula. "Defragmenting: Towards a critical understanding of the new global division of labour". Work Organisation, Labour and Globalisation, 1, 2: (2007): 1-4.

Iñigo Carrera, Juan. El capital: razón histórica, sujeto revolucionario y conciencia. Buenos Aires: Imago Mundi, 2003.

Iñigo Carrera, Juan. La Formación Económica de la Sociedad Argentina. Buenos Aires: Imago Mundi, 2007.

De Janvry, Alain, Elisabeth Sadoulet, and André Fargeix. "Politically feasible and equitable adjustment: Some alternatives for Ecuador." World Development 19, 11 (1991): 1577-1594. DOI:10.1016/0305-750X(91)90007-5

Khan, Mushtaq. "Rents, efficiency and growth", Chap 1 in Rents, rent-seeking and economic development: Theory and evidence in Asia. Cambridge: Cambridge University Press, 2000.

Kay, Rebecca and Sara, Kozameh. Ecuador's Economy Since 2007. Washington: The Center for Economic Policy and Research, 2007.

Laclau, Ernesto. "Modos de producción, sistemas económicas y población excedente" [Modes of Production, Economic Systems and Surplus Population], Revista Latinoamericana de Sociologia, 5, 2 (1969): 276-315.

Larrea, Carlos. Dolarización, crisis y pobreza en el Ecuador. Quito: IEE y CLACSO-CROP, 2004.

Leiva, Fernando. "Towards a Critique of Latin American Neostucturalism", Latin American Politics and Society, 50, 4, (2008); 1-25. DOI: 10.1111/j.1548-2456.2008.00028.x 
Marini, Ruy Mauro. Dialectica de la dependencia. Mexico: Ediciones Era, 1973/4

Marx, Karl. Capital, Vol I. London: Penguin, 1975.

Marx, Karl. Capital Vol III. London: Penguin 1981.

Mcneish John-Andrew and Owen Logan. "Rethinking responsibility and governance in resource extraction". Chap 1, edited by John-Andrew McNeish and Owen Logan Flammable SocietiesStudies on the Socio-economics of Oil and Gas. London: Pluto (2012): 1-46.

MCPE. “Agenda de la Política Económica para el Buen Vivir 2011-2013”. Ministerio de Coordinación de la Política Económica, [Coordinating Ministry for Political Economy] Quito: Ecuador, 2011: 98.

Muhr, Thomas. "(Re)constructing Popular Power in Our America: Venezuela and the regionalisation of 'revolutionary democracy' in the ALBA-TCP space", Third World Quarterly, 33, 2, (2012): 225-241. DOI: 10.1080/01436597.2012.666010

Muñoz, Fernando. "Forma de Estado y régimen político en el gobierno de Rafael Correa", in $E l$ correísmo al desnudo, edited by Alberto Acosta, Quito: Montecristi, (2013).

North, Lisa. "Militares y Estado en Ecuador: ¿construcción militar y desmantelamiento civil?" [State Building, State Dismantiling, and the Military in Ecuador]. Iconos Revista de Ciencias Sociales. 26 September (2006): 85-95.

Ospina, Pablo. "Ecuador: el nuevo período de gobierno y el cambio de la matriz productiva". Informe de coyuntura, 2013. Available at: http://www.cepecuador.org/images/PDFs/coyuntura_julio_2013.pdf

Ospina, Pablo. "Crisis y tendencias económicas en el Ecuador de Rafael Correa", Informe de coyuntura, 2015. Avaiable at:

http://www.cepecuador.org/images/PDFs/coyuntura_abril_2015.pdf

PNBV, Plan Nacional del Buen Vivir, [National Plan for Good Living] Secretaría Nacional de Planificación y Desarrollo (SENPLADES), Republica del Ecuador, Quito, 2013-2017.

Prebisch, Raul. The Economic Development of Latin America and its Principal Problems, New York: ECLAC, 1950.

Ramirez, Rene. La Virtud de los Comunes: De los paraísos fiscales al paraíso de los conocimientos abiertos [The Virtue of the Commons: From Fiscal Paradise to the Paradise of Open knowledge] Quito: Abya-Yala, 2014.

Rosales, Antulio. “Going Underground: the political economy of the 'left turn' in South America", Third World Quarterly, 34, 8, (2013): 1443-1457.

DOI:10.1080/01436597.2013.831538

Ruiz, Miguel. La Alquimia de la Riqueza: Estado, Petroleo, y Patron de Acumulacion en Ecuador, , Quito: Ecuador, CDES, 2013.

Saad-Fihlo, Alfredo and John Weeks. "Curses, Diseases and Other Resource Confusions", Third World Quarterly, 34, 1 (2013): 1-24. DOI:10.1080/01436597.2012.755010 
Sachs, Jeffrey and Andrew Warner. "The big push, natural resource booms and growth", Journal of Development Economics, 59 (1999); 43-76. DOI:10.1016/S0304-3878(99)00005-X

Singer, Hans "The distribution of gains between investing and borrowing countries", American Economic Review, 40, 2, (1950): 473-485.

Schumpeter, Joseph. Capitalism, Socialism and Democracy. London: Routledge, 1994.

Smith, Neil. Uneven Developmen. London: University of Georgia Press, 1984/2008.

The Organic Code for the Knowledge Economy (n/d), accessed 04/03/2016:

http://flacso.org.ar/wp-content/uploads/2015/07/Codigo-Ingenios.-MPI.pdf

Unda, Mario. "Modernización del capitalismo y reforma del Estado" in El correísmo al desnudo. Edited by Alberto Acosta. Quito: Montecristi (2013): 33-38.

Vercellone, Carlo, Francesca Bria, Andrea Fumagalli, Eleonora Gentilucci, and Alfonso Giuliani. "Managing the commons in the knowledge economy". The work leading to this publication has received funding from the European Union's Seventh Frame (2015): 110.

Villavicencio, Arturo. Innovacion Matriz Productiva y Universidad: Por que Yachay es una estrategia equivocada [Innovation, Productive Matrix and University: Why Yachay is the wormg strategy] Quito: Corporacion Editorial Nacional, 2015.

Vos, Rob "Uso de las divisas y dinámica de la industria manufacturera" [The Use of Foreign Exchnage and the Dynamic of Industrial Manufacturing] in La Investigacion Economica en el Ecuador, edited by Amali Mauro. Quito: ILDIS (1989): 235.

Weyland, Kurt. "The Political Economy of Market Reform and a Revival of Structuralism", Latin American Research Review, 42, 3 (2007): 235-50. DOI: 10.1353/lar.2007.0040

Yachay EP, "Expediente para constituir la ZEDE del Ciudad del Conocimineto "Yachay". Gobierno Nacional de la Republica del Ecuador, (2013): 88-9.

Zeller, Christian. "From the gene to the globe: Extracting rents based on intellectual property monopolies." Review of International Political Economy 15, 1 (2007): 86-115.

DOI:10.1080/09692290701751316 